\title{
Anatomy of a Tragedy: The Assisted Schools of British Columbia and the Death of Mabel Jones
}

\begin{abstract}
Alastair Glegg
The suicide of Mabel Jones in 1928 usually serves merely as an introduction to the story of Lottie Bowron, the Rural Teachers' Welfare Officer. This paper looks in more detail at the circumstances surrounding her death, examining the legal framework, the role of trustees and inspectors, the preparation of teachers, and the difficulties facing rural assisted schools. While these have been correctly identified as contributing to problems experienced by young teachers, they should not be allowed to obscure an equally important factor: the interaction of personalities in a specific situation. This, as much as any systemic educational problem, was ultimately responsible for her untimely death.

Le suicide de Mabel Jones en 1929 sert habituellement de simple introduction à l'histoire de Lottie Bowron, le fonctionnaire de l'assistance sociale des enseignants ruraux. Cet article approfondit les circonstances de la mort de Mabel Jones, en examinant le cadre légal, le rôle des administrateurs et des inspecteurs, la formation des maîtres et les difficultés des écoles rurales assistées. Ces facteurs ont bel et bien contribué aux problèmes rencontrés par les jeunes enseignants mais ils ne doivent pas masquer un facteur d'égale importance : l'interaction entre les personnalités lors d'une situation particulière. Ceci, tout autant que n'importe lequel problème éducatif systémique, fut en définitive responsable de sa mort prématurée.
\end{abstract}

Open your ears; for who will stop

The vent of hearing when loud Rumour speaks?...

Upon my tongues continual slanders ride...

Stuffing the ears of men with false reports. ${ }^{1}$

The 1928 suicide of a 20-year-old Vancouver Island teacher has been described elsewhere, but often serves merely as an introduction to the story of Lottie Bowron, the Rural Teachers' Welfare Officer appointed in response to the ensuing public outcry. ${ }^{2}$ This paper looks in more detail

1 William Shakespeare, Henry IV Part 2 (Oxford: Oxford University Press, 1958), Introduction, 1-8.

2 See, for example, Thomas Fleming, Carolyn Smyly, and Julie White, "Beyond

(C) Historical Studies in Education / Revue d'histoire de l'éducation 17, 1 (2005): 145-64 
at the circumstances surrounding her death, examining the legal framework, the role of school trustees and inspectors, the specific problems facing rural assisted schools, and the preparation of teachers. While these have been correctly identified as contributing to the problems faced by young teachers in rural one-room schools, they should not be allowed to obscure an elusive but equally important factor: the interaction of personalities in a specific situation. This, as much as any systemic educational problem, was ultimately responsible for Mabel Jones' untimely death.

During the early years of the twentieth century the Human Relations movement in business and administrative theory was in its infancy and Frederick W. Taylor's theories of scientific management and efficiency still dominated the thinking of leaders in the private and public sector. ${ }^{3}$ Professor Elton Mayo of the Harvard School of Business had proposed a different approach, claiming that "the problems of business are not merely scientific, they are human."” This suggestion was later supported by his studies at Western Electric's Hawthorne Works which examined the behaviour and productivity of workers, including young women of the same age as Mabel Jones, ${ }^{5}$ but the concept of an "organization personality" in which the organization assigns a role, and "specifies the particular values, facts, and alternatives" on which decisions are to be based, persisted. ${ }^{6}$ It would take several decades for administrative theory to develop to the stage of differentiating between what Jacob Getzels and Egon Guba described as the nomothetic and idiographic dimensions of the workplace, where

the organizational or administrative dimension is analyzed in terms of roles or job descriptions, each with its own set of behavioural (and attitudinal) expectations, while the personal... dimension is analyzed

Hope and Past Redemption: Lottie Bowron and the Rural School Teachers of British Columbia, 1928-1934," in School Leadership: Essays on the British Columbia Experience, 1872-1995, ed. Thomas Fleming (Mill Bay, BC: Bendall Books, 2001), 10132; and J. Donald Wilson, “'I am ready to be of assistance when I can': Lottie Bowron and Rural Women Teachers in British Columbia," in Children, Teachers and Schools in the History of British Columbia, ed. J. Barman, N. Sutherland, and J.D. Wilson (Calgary: Detselig, 1995), 285-306.

3 Frederick W. Taylor, The Principles of Scientific Management (New York: Harper and Bros., 1915).

$4 \quad$ Elton Mayo, "The Irrational Factor in Human Behaviour: The 'Night Mind' in Industry," The Annals of the American Academy 110 (Nov. 1923): 120.

$5 \quad$ F. J. Roethlisberger \& W. J. Dickson, Management and the Worker: An Account of a Research Program conducted by the Western Electric Company, Hawthorne Works, Chicago (Cambridge, MA: Harvard University Press, 1939). Increases in productivity appeared to be influenced more by personal and human factors than by working conditions.

6 Herbert A. Simon, Administrative Behaviour, $3^{\text {rd }}$ ed. (1946; New York: Free Press, 1976), 198. 
in terms of individual personality and its accompanying sets of "needs dispositions."7

Just because individuals are employed as teachers or elected as school trustees, with duties and responsibilities clearly prescribed and defined, it does not follow that their personal feelings and beliefs somehow become irrelevant. On the contrary, if these are in conflict with the requirements of the official role, then problems are likely to arise. It is not suggested that school inspectors and administrators were necessarily familiar with these theories, but advocates of the new Progressive Education were certainly moving in the same direction with their increased emphasis on the needs and capabilities of individual students. Unfortunately this attitude did not seem to extend to individual teachers, who continued to be regarded as constants rather than variables in educational equations, a situation that arguably has continued to this day.

\section{Assisted Schools, Trustees, and Teachers: The Official Framework}

Assisted schools in British Columbia in the 1920s rated much lower than city schools and rural municipal schools on every measure from facilities to teacher qualifications and salaries. ${ }^{8}$ Schoolhouses were provided by the community, but were usually temporary structures to be abandoned when the status of "rural school" was reached and the government would cover the cost of a new building. ${ }^{9}$ The salary of each teacher in an assisted rural school district was paid by the Minister of Finance, ${ }^{10}$ although this was amended in 1929 to allow part of the salary to come from a small local levy. ${ }^{11}$ The Council of Public Instruction in Victoria was authorized to make other grants for the establishment and maintenance of assisted rural schools, and thus there were no serious financial demands on the local community. ${ }^{12}$

7 Christopher Hodgkinson, Educational Leadership: The Moral Art (New York: State University Press of New York, 1991), 67. The original work on the nomothetic and idiographic dimensions appeared in J.W. Getzels and E.G. Guba, "Social behaviour and the administrative process.” School Review 65 (Winter 1957): 423-41.

8 For more on these small schools see for example Paul Stortz, "The Rural School Problem in British Columbia in the 1920s" (M.A. thesis, University of British Columbia, 1988); and Paul Stortz and J. Donald Wilson, "Education on the Frontier: Schools, Teachers and Community Influence in North-Central British Columbia," Histoire socialeSocial History 26, 52 (Nov. 1993): 265-90.

9 J.H. Putman and G.M. Weir, Survey of the School System (Victoria: King's Printer, 1925), 128 (hereafter Putman and Weir).

10 School Act, Revised Statutes of British Columbia 1924, Ch. 226, § 25 (2) (hereafter School Act, 1924); "No such generous treatment is to be found elsewhere in Canada," Putman and Weir, 189.

11 Public Schools Amendment Act, Statutes of British Columbia 1929, Ch. 55, § 9.

12 School Act, 1924, §§ 25 (1), 31. 
Day-to-day control of these schools, however, rested in the hands of a locally elected school board of three trustees, one of whom was appointed secretary and treasurer. ${ }^{13}$ Trustees had only to be British subjects, residents of the district, and qualified voters, later clarified as being over 21 years. ${ }^{14}$ To avoid the appearance of religious control of public schools no clergyman of any denomination could serve as a trustee, and ethnic minorities were also excluded. ${ }^{15}$ Trustees were elected for three-year terms on a rotating basis, and were officially required to meet at least once every three months, and to visit the school at least monthly. ${ }^{16}$

The school board was legally designated a corporation, meaning that technically individual trustees had no authority, and had the power "to select and appoint properly qualified persons as teachers....and to suspend any teacher with cause." 17 The board could "dismiss, in its discretion, any teacher," being merely required to give its reasons and thirty days notice to expire on July 31 or December 31. Upon notification from the Council of Public Instruction a teacher could at any time be given thirty days notice for "inefficiency or misconduct," or dismissed summarily for gross misconduct. ${ }^{18}$ Clearly a teacher's job was by no means secure, and this situation was made even worse by the oversupply of Normal School graduates in the 1920 s. $^{19}$ If a teacher wanted to resign he or she could only do so by giving notice thirty days before the end of term or before the annual school meeting in July. Otherwise release could only be obtained with the written consent of the board, without which the Council of Public Instruction was empowered to suspend the teacher's certificate. $^{20}$

The Provincial Superintendent of Education was required to provide trustees with copies of the School Act and School Regulations, ${ }^{21}$ and the local Inspector was supposed to "furnish trustees and teachers with such information as they [might] require regarding operation of this Act and the performance of their duties,"22 but this could hardly be described as adequate preparation. With over 800 school districts in the province,

13 School Act, 1924, §§ 9, 99.

14 Public Schools Amendment Act, 1929, § 22.

15 Clergymen were also prohibited from serving as superintendent, inspector, or even schoolteacher. Chinese, Japanese, Indians (i.e. Aboriginals), and Hindus were specifically identified as ineligible to vote. School Act, 1924, §§ 158, 94.

16 School Act, 1924, §§ 81-85, 98, 133 (1)(g).

17 School Act, 1924, \& 78.

18 School Act, 1924, § 133 (1).

19 Putman and Weir, 188. "Normal School” was the standard Canadian term for a teacher training college.

20 The only other option for a teacher who wanted to leave was for her to have accepted a position in another district between May 31 and August 31, or between November 30 and December 16. School Act, 1924, §§ 151-154.

21 School Act, 1924, § 6 (1)(c)

22 School Act, 1924, § 7 (1)(b). 
many in small isolated communities, it is hardly surprising that some of the trustees were quite unsuited for the position of public responsibility they assumed and the power which went with it. In addition, trustees were likely to be parents of pupils and often had very definite ideas about educational methodology, based entirely on their own limited school experience. Accommodation was frequently a problem for teachers in small communities, and many boarded with local families, so a teacher might have to deal with a school trustee not just as an employer, but also as a parent, and even perhaps as a landlord. It is hardly surprising that relationships were often strained.

Teachers in the assisted schools were the youngest group, with a median age of 23.6 years, compared with 25.0 for rural municipal schools, 28.2 for city elementary schools, and 35.9 for high schools. ${ }^{23}$ On average they had about three years of experience, but only stayed 18 months in any one school. ${ }^{24}$ About 80 per cent of the assisted school teachers were female and two-thirds of them held second-class certificates earned from the successful completion of eight months of Normal School teacher training. They earned on average $\$ 1,000$ a year, compared with the provincial average of $\$ 1,300$ for all elementary school teachers and $\$ 2,300$ for secondary teachers. ${ }^{25}$

The authorities were certainly aware of the problems associated with these little one-room schools, but to be fair it is difficult to see exactly what they could have done to solve them, given the provincial policy of opening a school wherever there were ten or more students. ${ }^{26}$ Many solutions were put forward, but they generally represented the particular viewpoint and priorities of the proponents. Few took into account the increasingly difficult financial situation facing governments during the 1920s.

J.H. Putman and G.M. Weir in their 1925 Survey of the School System gave the clearest picture, identifying most of the problems. They criticized some trustees, acknowledging that "local control of schools may deteriorate into a petty dictatorship which prates about local selfgovernment and the inherent rights of trustees and taxpayers."27 They recognized the inexperience of teachers, suggesting that "more supervision and training for ungraded schools would help remedy [their] weaknesses in organization," 28 and noted the "unattractive social

Putman and Weir, 178.

Ibid., 187.

British Columbia Department of Education, Annual Report of the Public Schools, 1926-27, M10, M24 (hereafter AR).

26 This official policy was roundly criticized by Alex Lord, former inspector and Normal School principal, although he did not want his views made public. See John Calam, Alex Lord's British Columbia (Vancouver: University of British Columbia Press, 1991).

27 Putman and Weir, 125.

28 Ibid., 128. 
conditions," including the problem of teacher accommodation. ${ }^{29}$ They were also aware of other factors which, as suggested above, have too often been overlooked: "It is doubtful if the teacher under nineteen or twenty years of age possesses the necessary degree of 'social' intelligence to enable her to get along successfully with senior pupils, trustees, and ratepayers." ${ }^{30}$ Their proposed solutions, however, were not particularly helpful. At their suggestion slightly more practice teaching was included in the training program, but this could hardly replicate the real-life situation. ${ }^{31}$ For two weeks students travelled daily by bus to conveniently located local schools where they taught in pairs under the guidance of a regular teacher. This, the Normal School Principal optimistically claimed, enabled them "more fully to appreciate the composite nature of the teacher's task." 32 Putman and Weir also recommended raising the age of admission to Normal School to eighteen, and showed a touching if somewhat naïve faith in the power of academic theory by suggesting that all prospective teachers should be required to take a course in Rural Sociology. ${ }^{33}$

The British Columbia School Trustees Association was equally vague, merely recommending "more all-round training...particularly training for rural school work, ${ }^{34}$ but the newly formed British Columbia Teachers' Federation was more specific in its proposals:

Problems to be faced in [rural] schools are often too great for solution by the young teacher...In the smaller and more scattered school districts...improvement might be effected by a change of local administration from the school board system now operative. Perhaps more direct control through the Education Department would give better results. ${ }^{35}$

They acknowledged that most school boards operated on "the principles of fair and square dealing," but recommended that the law should be amended "so as to make it impossible for any school board to dismiss unjustly a teacher." ${ }^{36}$ They hinted at trustee incompetence by seeking "recognition of expert opinion where the technical question of teaching efficiency is concerned."

Ibid., 188, 195.

Ibid., 210.

Following Putman and Weir's recommendation, the School Act was amended in

1925 to allow teachers in training free access to public schools for observation and practice teaching. Public Schools Amendment Act 1925, Ch. 46, §§ 12,16.

32 AR 1926-27, M52. Note the exemplary avoidance of the split infinitive.

33 Putman and Weir, 210, 212.

34 Ibid., 545.

35 Ibid., 533. It is hard to imagine today’s BCTF advocating this much government control.

36 Ibid., 537, and note 31 above.

37 Ibid. 
School inspectors were also aware of the problems, but their approaches varied as widely as their personalities. Some showed real understanding and sympathy for the difficulties faced by those who administered or taught in the isolated little schools. Alex Lord interspersed his terms as inspector with years of teaching at the Normal School, and brought to his teachers and students a practical and affectionate appreciation of the life and people of northern British Columbia, but unfortunately he was exceptional in this regard. ${ }^{38}$ A.C. Stewart, inspector for the west side of Vancouver Island at the time of Mabel Jones' death, showed something of the same humane approach, perhaps because he (like Lord) had been doing the job for over twenty years. In one of his Annual Reports he wrote of a local father and son and their contribution to education. The father had been a teacher for many years, and his son had been a principal: they "left their mark and influence in the profession and are remembered with gratitude and affection by many men and women." 39 This is in marked contrast to the style of his successor, W.H.M. May, whose approach was much more stern and official. In a typically critical comment he noted that

fluency in reading is not given the attention it deserves...In my opinion, there is far too much done for the child by the teacher...The class as a whole would make much better progress if the pupils were set to work upon matter understood and the teacher were to give individual attention to the weaker ones. ${ }^{40}$

It is hardly surprising that Mr. Stewart would be more conscious of the personal difficulties facing teachers, and there is a sadly prophetic ring to his report two years earlier:

It is probably needless to observe that local quarrels, bickering, and dissension over school matters and frequently unjust criticism of the teacher, her work and methods are not conducive to the best success in the school...Then, again, it is frequently said that teachers are not always all-wise, and very often by their conduct and lack of propriety and wisdom add fuel to the flames of criticism. In all other lines of human activity it is the general opinion that more allowance is made for the young and inexperienced than in the teaching profession. This is, I think, generally true, especially in rural districts. $^{41}$

\footnotetext{
38 For an account of his life and work see Calam, Alex Lord's British Columbia.

39 AR 1928-29, R24.

40 Mr. May took over the district from Mr. Stewart when the boundaries were altered at the beginning of 1929. AR 1928-29, R23-24.

41 AR 1926-27, M31.
} 
In 1927 he recorded the opening of a new school at Nixon Creek on Cowichan Lake, characteristically noting that it was an event "much appreciated by the men with families who follow the lumbering industry." 42 Just one year later that school's name was to be on the front page of every major newspaper in the province.

\section{The School at Nixon Creek, Camp 6, Cowichan Lake}

In 1882 the Victoria Land and Railway Company was given a land grant of approximately two million acres and exemption from taxation to build a railway up the east coast of Vancouver Island. Thirty years later the Esquimalt and Nanaimo Railway was leased to the Canadian Pacific Railway for 1.5 cents an acre annually, and the tax exemption continued. ${ }^{43}$ Along the railway towns and villages grew up, some permanent, and some transitory as the logging companies moved on. On account of the tax exemption, all rural schools in the E. and N. Railway Belt, as it was known in official documents, were classified as rural assisted schools, and thus funded almost entirely by the provincial government. ${ }^{44}$ This inequity was noted by Putman and Weir, who pointed out that some of those school districts were quite capable of taking on a greater share of the costs and were "not morally entitled to a continuance of the preferential treatment extended to them for the past quarter of a century." 45 There were 59 schools in the E. and N. Railway Belt of which 33 were one-room schools, with those in the larger centres having from two to five divisions. ${ }^{46}$ There were 110 teachers, of whom 90 were women, and 71 of them held second-class certificates. Only two possessed academic certificates, which required a university degree, and salaries ranged from $\$ 900$ to $\$ 1,500$ a year, averaging $\$ 1,047$, well below the provincial average. ${ }^{47}$

Camp 6 was a logging settlement at Nixon Creek on the southwestern shore of Lake Cowichan, and the first school there opened in September 1927. All the residents were employees of the Cowichan Lake Logging Company or their families, including sixteen children of school age. ${ }^{48}$ At the required meeting in August three trustees were elected, Mr. Robert Magnone as secretary and treasurer and Mrs. Malvina Peck (both parents of school children), together with Mr. William Miller. Miss

$42 \quad A R$ 1927-28, V21.

43 J. Hosie, "Esquimalt and Nanaimo Railway: Legislation respecting land grant and exemption from taxation therein," in Putman and Weir, 548.

44 School Act 1924, § 19.

45 Putman and Weir, 124.

46 The term "division" was used in place of the more specific "grade.” In a school with two or more teachers the children were split into divisions based roughly on their ability and progress.

47 AR 1927-28, V86, V88.

$48 \quad A R$ 1927-28, V87. 
Mabel Jones was hired as the school's first teacher at the base salary of $\$ 900$, of which $\$ 838$ was contributed by the government. ${ }^{49}$ The school house was a frame building in a forest clearing only a few yards from the dock, and accommodation for the teacher was provided in a room attached to the school, for which she paid $\$ 30$ a month. ${ }^{50}$

MABEL Estelle Jones was born in England on June 13, 1908, and so was just nineteen years old when she took up her first teaching position. Her parents Samuel and Mabel (née Martin) Jones had emigrated to Canada in 1913, and she grew up in the Vancouver Island mining town of Cumberland. ${ }^{51}$ She enrolled at the Victoria Normal School in 1926 to train as an elementary school teacher, and graduated eight months later with a Second-Class Certificate. ${ }^{52}$ She seems to have been a conscientious student, but perhaps not very outgoing, as her name does not appear as a member of any of the various clubs, societies, or sports teams. ${ }^{53}$ The yearbook entry describes her as her friends saw her:

A merry heart and full of fun,

In mischief she ranks second to none.

Mabel is small, but that does not mean she is not active - not at all!

Her class photograph shows a very pretty young woman looking gravely at the camera, her fair hair cut fashionably short and waved in the same style as all her classmates. ${ }^{54}$

She arrived in Nixon Creek in 1927 for the start of the school year and began teaching her class of seven boys and nine girls. Their range of ability and experience was typical of the one-room schools and she was fortunate to have such a small number of students: ${ }^{55}$

49 Ibid

50 B.C. Archives, British Columbia, Department of Education, Teachers' Bureau, GR0461, Box 2, File 8.

51 B.C. Archives, Death Certificate of Mabel Jones, Death Certificate Registration No.1928-09-396570, Microfilm B13132.

52 AR 1927-28, V87.

53 On the School District Information Form she completed in February 1928 she made no comments other than under "General living conditions," which she rated "Good.” This is in contrast to forms submitted by other teachers, who often went into some detail on the good and bad aspects of their schools. Under "Climatic conditions" she wrote "Temperature - much rain.” She presumably meant "Temperate," a term she would have learned in her geography class. Another similarly muddled young teacher used "Oceanic." B.C. Archives, British Columbia, Department of Education, Teachers' Bureau, GR-0461, Box 2, File 8.

54 University of Victoria Archives, LB1997, V5P7, Anecho [sic] of the Provincial Normal School of Victoria for 1926-1927, 43-44. Someone has drawn a black ribbon around her picture.

55 AR 1927-28, V87. 


$\begin{array}{ll}\text { Grade 1 } & 6 \\ \text { Grade 2 } & 4 \\ \text { Grade 3 } & 1 \\ \text { Grade 4 } & 2 \\ \text { Grade 5 } & 2 \\ \text { Grade 6 } & 1\end{array}$

She appears to have done her best to "teach diligently and faithfully" as required by the School Act, ${ }^{56}$ because Inspector Stewart visited the school a year later and was pleased with what he saw, stating that the progress of her classes was satisfactory, ${ }^{57}$ and that both discipline and schoolwork were good. ${ }^{58}$ There is a hint of progressivism in her methods, so she was trying to implement what she had been taught in Normal School. She encouraged the children to decorate their stories and notes with pictures cut from magazines, ${ }^{59}$ and her disciplinary methods stressed the writing of lines rather than other forms of punishment, ${ }^{60}$ an approach that would have pleased Putman and Weir, who insisted that "the atmosphere of the barracks and military camp should have little place in the elementary school." ${ }^{\text {"1 }}$ She could hardly be aware that these minor points would become so important later.

Predictably the attractive young teacher was made very welcome at Camp 6, especially by the male population. The company manager, Mr. Gilson, "felt a fatherly interest in her":

She was such a sweet and lovable girl that no-one could have known her and not worshipped her...We did everything in our power to maker her feel that she belonged to us, that she was part of our life. She was the camp sweetheart. ${ }^{62}$

She found her own sweetheart in a young brakeman, Arthur O’Neil, known to everybody in the camp as Pete. Her parents approved, they became engaged, and the wedding was set for June 1929. ${ }^{63}$ A new schoolhouse was constructed "according to government specifications," and better accommodation was provided. This was quite luxurious by most rural standards, and consisted of a furnished three-room cabin with a kitchen, a bedroom, and a sitting room. The residents "fixed up her

\footnotetext{
56 School Act 1924, § 152(g).

57 "School board is fired after girl's suicide," Vancouver Province, 21 Nov. 1928, 1. 58 B.C. Archives, British Columbia. Attorney General. Inquests and inquisitions conducted by coroners in British Columbia [1862], 1872-1937, GR-1327, Reel B02424, No. 351, Evidence of Robert Magnone, Coroner's Inquest into the death of Mabel Estelle Jones, Duncan, Nov. 16, 1928 (hereafter cited as “Evidence of...”).

59 Evidence of Arthur O’Neil.

60 Evidence of Robert Magnone.

61 Putman and Weir, 133.

62 Evidence of Christopher Gilson.

63 Evidence of Arthur O’Neil.
} 
cabin in a way that [they] thought she would appreciate, making it a little nicer for a girl away from home on her first job."64 "Everybody liked her so well," or at least appeared to do so, and it is hardly surprising that she was not initially aware of the growing undercurrent of gossip and spite among some of the women who resented the attention paid to the young teacher. ${ }^{65}$ Her fiancé was a little wiser, and refused to even enter her cabin:

It might have caused talk that would have been absolutely uncalled for and we both thought it better that I didn't go in. She was going to ask her mother a short time ago if it would be all right and then we decided that it probably would be better if I didn't go in at all. ${ }^{66}$

It is not hard to guess at the type of rumours that were circulated about the young couple, especially in an age that (however hypocritically) severely censured the behaviour of young women, especially if they happened to be teachers. To the strictly brought up Mabel Jones, suggestions of impropriety or promiscuity would have been shocking and hurtful, and certainly not something she could have mentioned to her mother or any other possible confidante. She had to wrestle with them alone.

By the start of her second year at Nixon Creek, with a larger class of twenty-two students, there were apparently only a few sources of worry for her. ${ }^{67}$ One was her mother's continuing ill-health, and she would have liked a bigger salary in order to help her. ${ }^{68}$ Another was some criticism of her work by a few parents. At a social gathering on Saturday, November 3, Manager Gilson made light of her concerns, pointing out that the Inspector knew more than any of the parents and that he had been pleased with her work. He told her to come to him if "any little criticisms" were made to her, and she replied "I will do that. I will always look upon you as my second father." ${ }^{\text {69 }}$ It was to be the last time he spoke to her. ${ }^{70}$

Ten days later Mabel's fiancé brought over her mail after he had finished work and stayed to split some firewood for her. Mr. Magnone, secretary of the school board, came to give her a note and the school flag which his wife had mended. Mabel read the note which contained four terse criticisms of her work:

Evidence of Christopher Gilson.

Evidence of Malvina Peck.

Evidence of Arthur O’Neil.

AR 1928-1929, R85.

Evidence of Arthur O’Neil.

The coroner noted later that in those small communities "it is not unusual to sort of

go to the Managing Director of the camp and get his views.”

70 Evidence of Christopher Gilson. 
Flag flying continually. To be raised and lowered every day; Careless manner in which the children are allowed to march into school;

School room discipline lacking;

Teacher allowing children to waste scribblers. Also the pasting of cut-outs in good scribblers.

She was very upset, and told him that the rope frequently got stuck and she could not get the flag down, that she often made the children march in two or three times, that on only three occasions had any parent even been into the school during class, and that pasting in pictures was "part of her plan of teaching the children." ${ }^{71}$ After Mr. Magnone left, Pete saw that she was still crying, and advised her not to take things so seriously. She said she was going to resign, but he persuaded her to go with him as planned to a little house party being held at Mr. and Mrs. Peck's home for a girl visiting from Vancouver.

They went to the party and had one dance, but Pete thought she "seemed blue" throughout the evening, and Mr. Gilson also noticed she looked depressed. ${ }^{72}$ She asked her fiancé to take her home early as she was tired, but for an hour or so in spite of the cold the young couple talked on the steps of her cabin. They discussed their wedding, which Pete wanted to bring forward to Christmas. This was "partly decided," but she was worried about her mother's illness and whether "she would be able to get things she thought necessary and to be the proper help to her parents in that time.” There was talk of her plan to resign and whether she should try to get another job, and when Pete finally left at 2:15 a.m. "she wasn't altogether in good spirits. She was still brooding over her mother's illness and these complaints and [he] thought probably after she had had a rest she might feel better."73

By nine o'clock the next morning, Tuesday, November 14, the teacher had not arrived at the schoolhouse, and there was no smoke coming from her chimney. A neighbour, Mrs. Dick, went over to see if she was unwell, and found her body on the floor. ${ }^{74}$ She was fully dressed, a small calibre rifle lay by her side, and she had left two notes, one for Mr. Gilson and the other for her fiancé. A tear-soaked handkerchief was crumpled up on the table. ${ }^{75}$ The manager was called, the cabin was locked, and an urgent message sent to the nearest police station in Duncan, 60 miles away. ${ }^{76}$ Constable Dunbar arrived at noon, saw there

Evidence of Robert Magnone and Arthur O’Neil.

Evidence of Christopher Gilson.

Evidence of Arthur O’Neil. An interesting sidelight on social life in a logging camp in the1920s is that leaving a party at 1:00 a.m. on a weekday was considered "early."

74 Evidence of Jane Dick. It is worth noting that even in this situation her fiancé asked a woman to enter her cabin to see if anything was wrong.

75 Evidence of Constable Dunbar.

76 The phone lines were down, so a boat was sent across the lake to Youbou with the 
was no doubt about the cause of death, and had her body taken by boat down the lake, and thence to the undertaker in Duncan. The inquest was set for two days later.

\section{Ascribing the Blame: The Coroner's Inquest}

The shocking news made headlines in the local newspapers, and the inquest was crowded. ${ }^{77}$ After the evidence of Constable Dunbar and of Dr. Bissett (who performed the autopsy), Mr. Gilson took the stand, and it was immediately apparent whom he held responsible for Mabel's suicide. He was much moved by her note which listed the four complaints about her teaching and continued:

\section{Dear Friend:-}

If you wonder at all why I did this you will find the reason above. There are a few people who would like to see me out of the way, so I am trying to please them. I tried to talk to you tonight. I wanted to tell you to help me to get another school. You said I was to look to you as a sincere friend - more than that. I know this is the coward's way out, but what they said about me nearly broke my heart. They are not true. Forgive me please. Say it was an accident. Mabel. ${ }^{78}$

This letter has been generally taken to refer just to the complaints about her teaching, but that is clearly not the case: those accusations were at least partly true, and she did not deny them. The things which nearly broke her heart must have been the other things which were being said about her; the whispered, evil, nasty things that were turning her happy and innocent romance into something sordid and dirty. Mr. Gilson certainly suspected this. He acknowledged that the complaints about her teaching were trivial, but

to this little girl, who had never heard a harsh word, they were mountains of criticism and they hurt. Added to this, perhaps, the little town small gossip and scandal that breathes from every scandal monger's lips...venomous scandal and gossip. ${ }^{79}$

news. Evidence of Constable Dunbar.

77 "Camp school teacher shot through head," Victoria Daily Colonist, 15 Nov. 1928, 1.

78 "Jury finds criticisms of trustees led girl teacher to kill self," Victoria Daily Colonist, 17 Nov. 1928, 1 and 2.

79 Evidence of Christopher Gilson.

80 Evidence of Arthur O’Neil. 
Her fiancé gave his account of the events of November 14, and explained what he thought she meant by her note to him, which ran "If only I could have married you at Christmas, then perhaps I wouldn't have cared what was said.” Somewhat naïvely he felt she was mainly worried about having enough money to afford her trousseau by Christmas. ${ }^{80}$

Then it was the turn of the trustees, whom the Coroner, Dr. Swann, treated harshly. Mr. Magnone admitted that he had had very few interviews with the young teacher, and that the only complaints had come from another trustee, Mrs. Peck, or "indirectly through my Missus.” They had not held a trustees' meeting since the first one a year before, there had been no monthly visits to the school, and he wrote the first two criticisms at the urging of Mrs. Peck. As for the comment on discipline, "I just took that in my own head" even though he had never visited the schoolroom. He admitted that his own two children were in a "far better" educational position than before, but claimed that Mabel had "not been a very good teacher" recently. ${ }^{81}$

Mrs. Malvina Peck did not come across well in court. ${ }^{82}$ She claimed to have read most of the School Act, and had "not an awful lot" of confidence in Inspector Stewart, who had given the teacher a good report. She admitted being responsible for some of the complaints, while trying to minimize her own role. She evaded the coroner's questions, but finally admitted that she "wanted to get rid of Miss Jones...for the children's sake," and replace her with a male teacher for "better discipline." She denied that she wanted the position for a friend of hers, and constantly tried to distance herself from Mr. Magnone’s actions: “I didn’t agree to take the complaint to Miss Jones. I didn't know until after. I didn’t agree to call a meeting...I had nothing to do with it.” The Coroner would have none of it. He suggested that she "knew that this young lady was very well liked around the camp and while you would like to get rid of her you were afraid to do it," and asked her if there was "absolutely no jealousy on any of the women's parts.” Mrs. Peck claimed that there was none as far as she was concerned, and she had never heard of any, but the Coroner again asked her if there was not "a certain amount of jealousy with regard to the attractiveness and popularity of this young lady." Her belated assertion that "she was a sweet little girl" ${ }^{3}$ clearly had little effect on the jury, whose verdict of 'suicide while temporarily insane' was unequivocal in where it laid the blame:

81 Evidence of Robert Magnone. This positive comment was somewhat negated when he also admitted that his children had never previously attended school.

82 A suitably Dickensian name, although "Malvina" is not as sinister as it sounds. The name was created by Scots poet James McPherson (1736-1796) for his celebrated but probably spurious translation of the Ossianic Poems from the Gaelic, and was possibly intended to mean "smooth brow." Sir Paul Harvey, Oxford Companion to English Literature (Oxford: Oxford University Press, 1958).

83 Evidence of Malvina Peck. 
We are of the opinion that [her] mental state was the result of unjustifiable, unfeeling and underhand criticisms of her work on the part of two members of the school board. Further we are of the opinion that the School Act should be amended in such a manner as to place the affairs of the school board in small, isolated, assisted districts in the hands of competent trustees, freeing the teacher from the gossip of irresponsible and petty citizens. ${ }^{84}$

THE PUBLIC RESPONSE to the findings of the inquest was one of outrage. Newspaper headlines on Vancouver Island and the Mainland read "Criticism of trustees led girl to kill self," "Coroner's jury finds criticism of school trustees led Miss Mable [sic] Jones to take her own life," and "Jury censures school board." 85 Portions of the evidence were reprinted verbatim, dwelling on the "pathetic story" of this "young woman of shy and retiring disposition., ${ }^{, 86}$ The rape and murder of another young teacher in Port Essington two years earlier was recalled, and although her death had nothing do with her job as a teacher, it helped emphasize the dangers faced by young women in isolated areas. ${ }^{87}$ There was great pressure on the government to do something, and it responded by immediately dismissing the Nixon Creek school board and replacing it with an official trustee, Inspector May. ${ }^{88}$ This, of course, did not solve the wider problem and the Minister of Education, Dr. Joshua Hinchliffe, reportedly received many anonymous complaints from teachers "so insecure that none dare voice a grievance." ${ }^{89}$ There was a statutory precedent which the government could have followed to change the control of assisted schools: the "Company Town Legislation" applied in areas without municipal organization, including land owned by a corporation that had been declared a regularly organized school district. In such cases the Council of Public Instruction could appoint "such persons, whether qualified voters or not, as they see fit" to act as trustees. ${ }^{90}$ In spite of the jury's recommendation they chose not to do this.

Instead they appointed a Rural Teachers' Welfare Officer, whose duty it would be "to visit the rural districts...where the living and social conditions under which young female teachers are working are not found

84 Verdict of Coroner's Inquest Jury, Mr. O. Smythe, Foreman (see note 58).

85 Victoria Daily Colonist, 17 Nov. 1928, 1; Nanaimo Free Press, 17 Nov. 1928, 1; Vancouver Province, 17 Nov. 1928, 3.

86 Vancouver Province, 21 Nov. 1928, 1.

87 See Joan Adams and Becky Thomas, Floating Schools and Frozen Inkwells: The One-Room Schools of British Columbia (Madeira Park, BC: Harbour Publishing, 1985).

88 Vancouver Province, 21 Nov. 1928, 1.

89 "B.C. school teachers and school trustees," E.J. Comyn, letter to the editor, Vancouver Province, Magazine Section, 9 Dec. 1928, 1.

90 School Act 1924, § $128(1,2)$. 
to be satisfactory." ${ }^{91}$ Miss Lottie Bowron was appointed to this position, ${ }^{92}$ and contrary to most expectations carried out the task with considerable success for the next five and a half years, ${ }^{93}$ reporting that teachers felt "a sense of security in the fact that there is a woman to whom they may appeal and who from time to time visits them." 94 There was however one subsequent amendment to school legislation which may or may not be connected with these events. On March 20, 1929, the following section was added to the School Act: "No [legal] action shall be brought against a trustee of any school district or against any Board of School Trustees in its corporate capacity...unless within three months of the act committed." ${ }^{95}$ It may, of course, be only coincidence that this amendment was passed just four months after Mabel Jones’ death.

A COMBINATION of professional and personal factors contributed to the tragic climax of the events at Nixon Creek. First, as noted above, the statutory provisions governing the hiring and firing of teachers were heavily weighted in favour of the school trustees. In the case of Mabel Jones it is apparent that she believed that the note she received was a formal communication from the school board and that she was on the verge of dismissal. The coroner certainly took this view, and concluded his examination of Mrs. Peck by reiterating it:

Do you think that when [the letter of complaint] is brought to her by the secretary of the school board that she would be justified in assuming that it came from the school board?...Y You know perfectly well that if the secretary of the school board came with a complaint that you would assume that it was from the school board. ${ }^{96}$

Her denials of his allegations were not very convincing.

Next, the dates themselves are suggestive. If the school board wanted to get rid of her they had merely to give thirty days notice to expire on December 31, but if Mabel wished to leave she had to give notice thirty days before the end of term, which was generally the end of the second week in December. ${ }^{97}$ December 14,1928 , was a Friday, exactly a month

\footnotetext{
$91 \quad$ AR 1928-29, R10.

92 “Miss Bowron made advisor for teachers,” Victoria Daily Colonist, 11 Dec.1928, 1 and 2.

93 For details of her career in this position see the articles cited in note 2.

94 AR 1928-29, R34.

95 Public Schools Amendment Act, Statutes of British Columbia 1929, Ch. 55, § 131

(a).

96 Evidence of Malvina Peck. The point made previously (note 17) about the corporate status of the board is relevant here. Mr. Magnone and Mrs. Peck, whether deliberately or not, were clearly acting as individuals and not as trustees. It would however be unreasonable to expect a young teacher to appreciate this distinction.

97 School Act 1924, §§ $133(1)(\mathrm{c}), 152(\mathrm{j})$.
} 
after her suicide on November 14 . Whether or not this was a contributing factor can be only a matter for speculation, but we do know that she discussed her possible resignation with her fiancé at their last meeting, and it is quite possible that in her confusion and distress she thought she would be unable to resign before Christmas. Being dismissed would almost certainly mean she would be unable to obtain another position to earn the money she felt she needed. ${ }^{98}$

Finally, eight months training after high school was quite insufficient preparation for making independent professional decisions, and novice teachers naturally tended to do exactly as they had been instructed, showing "a natural reluctance to depart from the official programme of studies." "99 Two of the criticisms aimed at Mabel's teaching related specifically to this, the first being the matter of discipline. The proponents of what was soon to be called "Progressive Education" were very outspoken in condemning the rigidity and harshness of traditional classroom management practices, noting with regret that it was

not uncommon for a lady teacher in a school with an enrolment of eight or ten pupils to adopt the practices of the parade ground in the management of her classes...Why? Usual response "discipline."

Student teachers were aware of this trend, and had been encouraged to take a different approach such as the writing of lines, but often this was not what the trustees and parents wanted. ${ }^{101}$ Nor did many trustees appreciate a departure from what they remembered as the "proper" way of teaching. Illustrating stories with cut-out pictures was merely "wasting good scribblers," and Mr. Magnone claimed that while his children "had been going to school up there they had used more scribblers than he had used in all his school days." ${ }^{102}$ Petty criticisms, of course, but Mabel was just doing what she had been taught to do.

On the personal side, Mabel's worries over her mother's health, her upcoming marriage, and the financial implications of both have already been described, as has the undercurrent of jealous and spiteful gossip, and these were critically important factors in her irrevocable final decision. It is not to belittle them, however, to point out that many other young teachers faced similar problems. Bullies are quick to discover the weaknesses of others, and in Mabel Jones they found a natural victim. Shy, retiring, and somewhat naïve, the young teacher was anxious to please and to do well, and previously had always been treated with gentle affection. The direct and implied criticisms of her professional and

\footnotetext{
98 Evidence of Arthur O’Neil.

99 Putman and Weir, 129.

100 Ibid., 133.

101 Evidence of Robert Magnone and Malvina Peck.

102 Evidence of Arthur O’Neil.
} 
personal life were unexpected and devastating to "the sweet kind innocent little girl that never had an unkind word said to her, with loving parents and a loving brother."103

But there were also those who would not be intimidated. In 1927, just when Mabel went to Nixon Creek, another young teacher named Mildred McQuillan took a position in Orange Valley, a tiny northern settlement near Fraser Lake, and hated it from the first day. Defiantly she refused to conform to convention, daring to smoke cigarettes and to complain of the lack of male company. She used her diary as a safety valve to blow off steam:

I get out some dough to pay my board and Holy dying catfish, Church on fire! Suffering Tomcats! Holy smokers! Ye gods! My stars! Dirty Dying Dora! Damn - absolute robbery! Outrageous - I have to pay up 35 bones for this dive!

She even forfeited her final paycheque - "I don't give a rip I'm closing a week or more early" - and headed back to civilization. ${ }^{104}$ She would have made short work of Malvina Peck and the gossips of Nixon Creek. So too would Mary Williams, who closed down her school at Mud River for a day in order to go to Prince George to see her family, go shopping, and visit the cinema. She enjoyed arguing socialist politics with her landlord, and was so incensed when he patronizingly addressed her as "Dear" in front of the hired hands that she immediately walked out of the house and took lodgings elsewhere. ${ }^{105}$ Drawing on numerous interviews with teachers and pupils from one-room schools. Joan Adams and Becky Thomas came to this conclusion:

The truth is that many of the frightful encounters of greenhorn teachers were of an imaginary nature...The actions of animals, the hazards of the weather, and the eccentricities of some local characters, even situations with some danger, could all be handled sensibly. Teachers who had been two or three years in the country had very few encounters with the unknown. ${ }^{106}$

None of this, of course, detracts from the personal tragedy of Mabel Jones and her family and friends. For twenty years after her death her parents offered board and lodging to young teachers in Cumberland, providing the caring and supportive environment their daughter so

103 Evidence of Christopher Gilson.

104 B.C. Archives, MS-1252, Personal diary of Mildred McQuillan.

105 B.C. Archives, MS-261, Personal diary of Mary Williams. See also Thomas Fleming and Carolyn Smyly, "The Diary of Mary Williams: A Cameo of Rural Schooling in British Columbia, 1922-1924,” in School Leadership, ed. Fleming, 369-404.

106 Adams and Thomas, Floating Schools and Frozen Inkwells, 100. 
desperately needed in Nixon Creek. ${ }^{107}$ Her work was continued by Miss E. M. Fox, and virtually no class time was lost as the school was in operation for 183.5 days between September 1928 and June 1929. ${ }^{108}$ By the next September there were twenty-seven pupils in the school, and Miss Fox had upgraded her qualifications to a First-Class Certificate, resulting in a salary increase of $\$ 60$ a year. ${ }^{109}$ As the task of preparing young British Columbians for the future continued, schools grew bigger and more centrally located, school administration at all levels became more efficient, and teachers were better trained and prepared. Proponents of the new Progressive Education, with its "commitment to a childcentred, relatively unstructured curriculum, allowing a considerable freedom of choice to pupil and teacher alike, the expression of a humane, egalitarian, democratic philosophy of education," were changing attitudes to schooling. ${ }^{110}$ The advocacy of the B.C. Teachers' Federation helped bring about improvements in working conditions, and by 1934 the position of Rural Teachers Welfare Officer was discontinued as no longer being necessary. ${ }^{111} \mathrm{~A}$ terrible price had been paid for the standards of living and employment today's educators take for granted, and to this extent at least the young teacher's life was not entirely wasted.

If it is correct that "the problem of administration is the reconciliation of the nomothetic and idiographic dimensions" in the goals and operations of an organization, ${ }^{112}$ then it should be the responsibility of the historian of education to bring the same balance to accounts of the past. The formal and legal context of schooling is often recorded, relying heavily on statistics, official documents, legislation, and government reports. There are also many accounts of personal experiences, which are usually based primarily on anecdotal evidence, private documents, and personal memories. Rules and regulations about schooling are put in place with the best of intentions, but cannot take into account the human element. Teachers and trustees are not ciphers or statistics but individuals with the usual mixture of human strengths, weaknesses, and emotions. Sweeping generalizations about "teachers" are still common, as if a sixtyyear-old male senior chemistry teacher is somehow no different from a young woman starting her first job in a Grade 2 classroom. The story of Mabel Jones demonstrates that an appreciation of the interaction between the organizational and personal aspects of education is essential if the

107 Personal communication to the author from Marilyn Simms, 16 Nov. 2003.

108 AR 1928-29, R85.

109 AR 1929-30, Q86.

110 Jean Mann, "G.M. Weir and H.B. King: Progressive Education or Education for the Progressive State," in Schooling and Society in $20^{\text {th }}$ Century British Columbia, ed. J. Donald Wilson and David C. Jones (Calgary: Detselig, 1980), 91.

111 There was also a political side to the decision on her dismissal. See Fleming, Smyly, and White, "Beyond Hope and Past Redemption," and Wilson, "I am ready to be of assistance when I can.”

112 Christopher Hodgkinson, Towards a Philosophy of Administration (Oxford: Blackwell, 1978), 215. 
lessons of the past are to be useful in understanding the present and shaping the future. 